\title{
Peran Guru Bimbingan dan Konseling Dalam Meningkatkan Minat Melanjutkan Studi ke Perguruan Tinggi
}

\author{
Afiatin Nisa \\ Universitas Indraprasta PGRI \\ Afiatinnisa83918@gmail.com
}

Submitted: 03-05-2018, Revised : 24-05-2018, Accepted : 20-06-2018

\begin{abstract}
The purpose of this research is to know the role of teacher guidance and counseling in increasing interest to continue study to university at student at SMK Nurul Hikmah Bekasi. The research method used by the researcher is qualitative method with descriptive approach, that is by spreading the questionnaire, observation, and interview with what is from a symptom of phenomenon that exist when research done data and data source in this research is teacher guidance and counseling and student of SMK Nurul Hikmah Bekasi. The research instrument used in this research is questionnaire, interview, observation and documentation. Survey and observation result data after check and recheck the validity of the data then described what it is. After analyzing the researchers, it can be concluded that the role of teacher guidance and counseling in providing services to foster interest to continue studies to college students in SMK Nurul Hikmah done optimally. Keywords: College; guidance; counseling
\end{abstract}

\begin{abstract}
Abstrak: Tujuan dari penelitian ini adalah untuk mengetahui peran guru bimbingan dan konseling dalam meningkatkan minat melanjutkan studi ke Perguruan Tinggi pada siswa di SMK Nurul Hikmah Bekasi. Metode penelitian yang digunakan peneliti adalah metode kualitatif dengan pendekatan deskriptif, yaitu dengan cara menyebar angket, observasi, dan wawancara dengan apa adanya dari suatu gejala akan fenomena yang ada ketika penelitian dilakukan data dan sumber data dalam penelitian ini adalah guru bimbingan dan konseling dan siswa SMK Nurul Hikmah Bekasi. Instrumen penelitian yang digunakan dalam penelitian ini adalah angket, wawancara, obervasi dan dokumentasi. Data hasil survey dan observasi setelah dilakukan cek dan recek keabsahan datanya kemudian dideskripsikan apa adanya. Setelah peneliti menganalisa, maka dapat ditarik kesimpulan bahwa peran guru bimbingan dan konseling dalam memberikan layanan untuk menumbuhkan minat untuk melanjutkan studi ke perguruan tinggi pada siswa di SMK Nurul Hikmah dilakukan secara maksimal.
\end{abstract}

Kata Kunci: Perguruan tinggi; bimbingan; konseling

\section{Pendahuluan}

Pendidikan merupakan hal yang penting dan tidak dapat dipisahkan dari kehidupan manusia. Setiap manusia berhak mendapatkan pendidikan. Bagi individu dan masyarakat, pendidikan adalah aset yang tak ternilai. Pendidikan tidak pernah dapat dideskripsikan secara gamblang hanya dengan mencatat banyaknya jumlah siswa, personel yang terlibat, harga bangunan, dan fasilitas yang dimiliki. Pendidikan memang menyangkut hal itu semua, namun lebih dari itu semuanya. Pendidikan merupakan proses yang esensial untuk mencapai tujuan dan cita-cita setiap individu. Secara filosofis dan historis pendidikan menggambarkan suatu proses yang melibatkan berbagai faktor dalam upaya mencapai kehidupan yang bermakna, baik bagi individu sendiri maupun maasyarakat pada umumnya.

Pendidikan secara tradisional dilihat sebagai hubungan pedagogik antara guru dan pelajar. Guru selalu yang memutuskan apa yang pelajar perlu tahu, dan memang bagaimana pengetahuan dan keterampilan harus diajarkan kepada pelajar. Kurang lebih dalam tiga puluh tahun terakhir ini telah terjadi cukup revolusi dalam dunia pendidikan melalui penelitian dari proses belajar tersebut. Pendidikan sudah dapat diberikan pada masa kanak-kanak hingga sampai pada masa dewasa. Jenjang pendidikan dimulai dari pendidikan sekolah dasar sampai dengan pendidikan ke perguruan tinggi.

Para siswa memandang sekolah sebagai lembaga yang dapat mewujudkan cita-cita mereka. Sementara orang tua menaruh harapan kepada sekolah untuk dapat mendidik siswa 
agar menjadi orang pintar, terampil, dan berakhlak mulia. Apa yang diharapkan dari pendidikan untuk perkembangan siswa, setiap negara atau bangsa memiliki orientasi dan tujuan yang relatif berbeda. Bagi kita bangsa Indonesia, kontribusi pendidikan yang diharapkan bagi perkembangan para siswa termasuk dalam Undang-Undang No.20 tahun 2003 Bab II Pasal 3 yang berbunyi sebagai berikut:

Pendidikan nasional berfungsi mengembangkan kemampuan dan membentuk watak serta peradaban bangsa yang bermatabat dalam rangka mencerdaskan kehidupan bangsa, bertujuan untuk berkembangnya potensi siswa agar menjadi manusia yang beriman dan bertakwa kepada Tuhan Yang Maha Esa, berakhlak mulia, sehat, berilmu, cakap, kreatif, mandiri, dan menjadi warga negara yang demokratis serta bertanggung jawab.

Fungsi dan tujuan pendidikan tersebut menunjukkan karakter pribadi siswa yang diharapkan terbentuk melalui pendidikan. Klausul undang-undang ini memberikan implikasi imperatif terhadap semua penyelenggaraan pendidikan, baik formal, maupun nonformal agar senantiasa mengorientasikan untuk membangun karakter siswa yang mempunyai cita-cita dan tujuan dalam berprestasi.

Dalam Kamus Besar Bahasa Indonesia (Depdiknas, 2001: 744), kata minat memiliki arti kecenderungan hati yang tinggi terhadap sesuatu, gairah, keinginan. Jadi harus ada sesuatu yang ditimbulkan, baik dari dalam dirinya maupun dari luar dirinya untuk menyukai sesuatu. Berhubung dengan minat untuk melanjutkan pendidikan ke perguruan tinggi, maka guru bimbingan dan konseling diharapkan dapat memberikan arahan dan layanan kepada siswa yang akan segera lulus untuk melanjutkan kembali pendidikan perguruan tinggi.

Prayitno dan Amti mengemukakan bahwa bimbingan adalah proses pemberian bantuan yang dilakukan oleh orang yang ahli kepada seseorang atau beberapa orang individu, baik anak-anak, remaja, maupun dewasa, agar orang yang dibimbing dapat mengembangkan kemampuan dirinya sendiri dan mandiri, dengan memanfaatkan kekuatan individu dan sarana yang ada dan dapat dikembangkan berdasarkan norma-norma yang berlaku (Prayitno \& Amti, 2009). Sedangkan Crow dan Crow (dalam Daryanto dan Farid) mengemukakan bahwa bimbingan adalah bantuan yang diperlukan seseorang, laki-laki atau perempuan yang memiliki kepribadian yang memadai dan terlatih dengan baik kepada individu-individu setiap usia untuk membantunya, mengatur kegiatan hidupnya sendiri, mengembangkan pandangan hidupnya sendiri membuat keputusan sendiri dan menanggung bebannya sendiri (Daryanto \& Farid, 2015).

Teori lainnya menjelaskan bimbingan adalah proses bantuan terhadap individu untuk mencapai pemahaman diri dan pengarahan diri yang dibutuhkan untuk melakukan penyesuaian diri secara maksimum kepada sekolah, keluarga, serta masyarakat (Wardati \& Jauhar, 2011). Gantina Komalasari dkk menegaskan bahwa bimbingan dapat dimaknai sebagai proses bantuan yang memiliki tujuan membantu individu membuat keputusan penting dalam hidupnya yang biasanya terjadi pada sering pendidikan atau persekolahan. Bimbingan lebih bersifat pencegahan yaitu bantuan yang dilakukan untuk membantu individu dalam beradaptasi dan mencapai proses perkembangannya baik secara pribadi, intelektual, sosial, emosi dan karirnya(Gantina, Komalasari, \& Wahyuni, 2011).

Dari beberapa definisi di atas, dapat disimpulkan bimbingan adalah bantuan yang diberikan oleh seseorang, kepada orang lain yang memerlukannya. Kata "membantu" berarti dalam bimbingan tidak ada paksaan, tetapi lebih menekankan pada pemberian peranan individu ke arah tujuan yang sesuai dengan potensinya. Jadi dalam hal ini, pembimbing sama sekali tidak ikut menentukan pilihan atau keputusan dari orang yang dibimbingnya. Yang menentukan pilihan atau keputusan adalah individu itu sendiri. Proses bimbingan pada umumnya berbeda dengan proses konseling, Wardati dan Jauhar menyatakan bahwa: 
"konseling merupakan salah satu teknik pelayanan bimbingan secara keseluruhan, yaitu dengan cara memberikan bantuan secara individual atau face to face relationship"(Wardati \& Jauhar, 2011). Selanjutnya Daryanto dan Farid menyatakan bahwa: "konseling itu merupakan bantuan yang diberikan seorang konselor kepada seorang klien agar klien tersebut bisa menyesuaikan diri baik dirinya sendiri maupun ketika ia berada didekat lingkungannya"(Daryanto \& Farid, 2015). Berbeda dengan Bernard \& Fullmer (dalam Prayitno dan Amti, 2004: 93-103) mendefinisikan konseling sebagai pemahaman dan hubungan individu untuk mengungkapkan kebutuhan-kebutuhan, motivasi, dan potensi-potensi yang unik dari individu dan membantu individu yang bersangkutan untuk mengapresiasi ketiga hal tersebut"(Prayitno \& Amti, 2009).

Gladding (dalam Gantina Komalasari, 2011: 16), menegaskan bahwa :"Konseling memiliki perbedaan yang signifikan dengan psikoterapi. Gladding mengutip definisi konseling yang dikemukakan oleh The American Counseling Association (ACA): konseling merupakan aplikasi dari prinsip-prinsip kesehatan mental, psikologi, atau perkembangan karir, tetapi juga patologi"(Gantina et al., 2011). Berbeda dengan bimbingan, terminologi konseling lebih menekankan pada pelayanan profesional yang lebih khusus. Hal ini terlihat dari definisi yang dikemukakan oleh Prayitno bahwa: "konseling adalah proses pemberian bantuan yang dilakukan melalui wawancara konseling oleh seorang ahli (disebut konselor) kepada individu yang sedang mengalami sesuatu masalah (disebut klien) yang bermuara pada teratasinya masalah yang dihadapi oleh klien"(Prayitno \& Amti, 2009).

Dapat dipahami bahwa konseling merupakan salah satu bentuk layanan bimbingan yang khusus diberikan seseorang secara terkemuka untuk membantu mengatasi masalah yang dihadapi. Sehubungan dengan itu, maka guru bimbingan dan konseling yang menangani layanan konseling perlu memiliki persyaratan tertentu yang lebih banyak dari pada guru lainnya agar mampu mendekati berbagai masalah yang dihadapi siswa sekaligus membantu mencarikan alternatif pemecahannya. Berdasarkan uraian-uraian yang telah dikemukakan di atas, maka dapat disimpulkan bahwa bimbingan dan konseling adalah kegiatan yang melalui proses berkesinambungan secara terus menerus dan sistematis yang dilaksanakan oleh seorang konselor untuk membantu konseli sehingga konseli dapat mandiri dalam mengambil keputusan secara efektif dan produktif.

Meskipun terdapat dua kata, yaitu bimbingan dan konseling, akan tetapi bimbingan dan konseling merupakan suatu kata yang saling melengkapi. Bimbingan dan konseling merupakan salah satu komponen dalam satuan sistem pendidikan khususnya di sekolah. Guru sebagai salah satu pendukung unsur pelaksana pendidikan yang mempunyai tanggung jawab sebagai pendukung pelaksana layanan bimbingan dan konseling pendidikan di sekolah, dituntut memiliki wawasan yang memadai terhadap konsep-konsep dasar bimbingan dan konseling di sekolah. Penerapan layanan secara menyeluruh di sekolah dengan sendirinya akan banyak membantu guru dalam melihat minat siswa terhadap pendidikan di sekolah. Secara tidak langsung minat merupakan salah satu pendukung aktivitas dan prestasi siswa.

Djamarah dan Zain menyatakan bahwa minat merupakan kecenderungan yang menetap untuk memperhatikan dan senang beberapa aktivitas (Djamarah, Syaiful, \& Zain, 2002). Senada dengan Muhibbin yang menyatakan bahwa: "minat (interest) adalah kecenderungan dan kegairahan yang tinggi atau keinginan yang besar terhadap sesuatu"(Syah, 2010), selanjutnya Mulyasa menyatakan bahwa: "minat (interest) adalah kecenderungan seseorang untuk melakukan sesuatu perbuatan"(Mulyasa, 2003). Berbeda dengan Usman yang menyatakan bahwa: "minat adalah suatu sifat yang relatif menetap pada diri sesorang, minat sangat besar terhadap pengaruhnya terhadap belajar sebab dengan minat, seseorang akan melakukan sesuatu yang diminatinya"(Usman, 2017). Slameto (dalam Djamarah dan Bahri) menekankan bahwa: "minat adalah suatu rasa lebih suka dan rasa ketertarikan pada suatu hal atau aktivitas, tanpa ada menyuruh"(Djamarah et al., 2002). 
Dari pernyataan beberapa diatas, dapat ditarik kesimpulan bahwa seseorang yang berminat terhadap suatu aktivitas akan memperhatikan aktivitas itu secara konsisten dengan rasa senang dikarenakan hal tersebut datang dari dalam diri seseorang yang didasarkan rasa suka dan tidak adanya paksaan dari pihak luar. Minat merupakan alat motivasi yang utama yang dapat membangkitkan kegairahan belajar siswa dalam rentangan waktu tertentu. Minat melanjutkan studi merupakan pernyataan psikis yang menunjukkan seseorang untuk memusatkan perhatian pada suatu objek atau aktivitas untuk mengembangkan dirinya menuju kelanjutan studi setelah lulus sekolah.

Dalam hal ini guru Bimbingan dan Konseling bisa memberikan layanan berupa layanan informasi, Prayitno dan Amti mengemukakan bahwa: "layanan informasi dalam rangka pelayanan bimbingan dan konseling terdapat tiga jenis informasi, yaitu informasi pendidikan, informasi jabatan, dan informasi sosial budaya". Dalam kaitannya dengan judul minat siswa untuk melanjutkan ke perguruan tinggi, guru bimbingan dan konseling memberikan layanan informasi pendidikan kepada siswa yang ingin melajutkan studinya ke perguruan tinggi. Banyak siswa mengalami kesulitan dalam menentukan pilihan untuk memilih perguruan tinggi yang tepat sesuai kemampuan dririnya pemilihan program studi seperti: (Prayitno \& Amti, 2009)

1. Pemilihan sekolah, falkultas dan jurusan

2. Penyesuain diri dengan program studi

3. Penyesuaian diri terhadap suasana belajar

4. Putus sekolah

Berdasarkan observasi dari siswa SMK Nurul Hikmah Bekasi, banyaknya siswa yang memilih bekerja setelah lulus dibandingkan melanjutkan pendidikan ke perguruan tinggi karena berbagai alasan seperti kurangnya minat melanjutkan pendidikan ke perguruan tinggi, kurang tahunya informasi yang mengenai manfaat melanjutkan pendidikan ke perguruan tinggi, dan berbagai macam alasan lainnya. Pada tahap ini sangatlah dibutuhkan peran guru bimbingan dan konseling dalam upaya meningkatkan minat siswa dalam melanjutkan pendidikan ke perguruan tinggi dan memberikan berbagai informasi mengenai pentingnya melanjutkan pendidikan ke perguruan tinggi.

Berdasarkan latar belakang masalah yang telah dikemukakan di atas, maka tujuan penelitian ini adalah untuk menganalisis Peran Guru Bimbingan dan Konseling dalam Meningkatkan Minat Melanjutkan Studi ke Perguruan Tinggi pada Siswa di SMK Nurul Hikmah Bekasi.

\section{Metode Penelitian}

Dalam menganalisis peran guru bimbingan konseling peneliti menggunakan metode kualitatif. Pengambilan sampel dalam penelitian ini bertujuan untuk mengetahui peran guru bimbingan konseling dalam meningkatkan minat siswa kelas XII TKJ dan XII AP di SMK Nurul Hikmah Bekasi melanjutkan studi keperguruan tinggi. Teknik pengambilan sampel dalam penelitian ini yaitu dengan purposive sampling. Terdapat 100 siswa akan tetapi dengan beberapa pertimbangan peneliti membatasi hanya 40 siswa yang menjadi sampel penelitian. 40 siswa terdiri dari 20 siswa pada kelas XII jurusan TKJ dan 20 siswa pada kelas XII jurusan AP.

Kelengkapan data penelitian didapatkan dengan memanfaatkan hasil observasi, wawancara dan kuesioner. Wawancara yang digunakan adalah wawancara tidak terstruktur, yaitu wawancara yang bebas dimana peneliti tidak menggunakan pedoman wawancara yang telah tersusun secara sistematis dan lengkap untuk pengumpulan datanya. Pedoman wawancara yang digunakan hanyar. wawancara berupa garis-garis besar permasalahan yang akan ditanyakan. 


\section{Hasil dan Pembahasan}

Tabel 1. Hasil Interpretasi Data

\begin{tabular}{llccc}
\hline No & $\begin{array}{c}\text { Alternatif } \\
\text { Jawaban }\end{array}$ & $\begin{array}{c}\text { Frekuensi } \\
\text { Jawaban }\end{array}$ & $\begin{array}{c}\text { Presentase } \\
(\boldsymbol{\%})\end{array}$ & Item Soal ini \\
\hline $\mathbf{1}$ & Sangat Baik & 0 & 0 & 0 \\
$\mathbf{2}$ & Baik & 15 & 50 & $1,4,12,13,14,15,16,18,20$, \\
$24,25,26,28,29,30$
\end{tabular}

Berdasarkan hasil interpretasi data yang telah diinterpretasikan, terlihat interpretasi kategori Sangat Baik 0\%, kategori Baik 50\%, kategori Cukup 46,7\%, kategori Kurang Baik 3,3\%, dan kategori Sangat Kurang Baik 0\%. Dari data tersebut, maka dapat diinterpretasikan peran guru bimbingan konseling dalam meningkatkan minat siswa melanjutkkan studi ke perguruan tinggi dalam kategori Baik.

1. Hasil Wawancara

Hasil wawancara dengan guru bimbingan dan konseling SMK Nurul Hikmah Bekasi dapat ditarik kesimpulan beberapa item, yaitu:

a. Guru bimbingan dan konseling memberikan motivasi kepada siswa untuk menumbuhkan minat siswa melanjutkan studi ke perguruan tinggi;

b. Guru bimbingan dan konseling memberikan layanan program bimbingan dan konseling berupa layanan konseling individu untuk menumbuhkan minat siswa melanjutkan studi ke perguruan tinggi;

c. Jenis bimbingan yang diberikan oleh guru bimbingan dan konseling kepada siswa berupa bimbingan kelompok, bimbingan belajar, dan bimbingan karir;

d. Dari hasil wawancara dengan guru bimbingan dan konseling menjabarkan beberapa kendala mengenai menumbuhkan minat melanjutkan studi ke perguruan tinggi, yaitu adanya siswa yang masih ragu untuk melanjutkan studi ke perguruan tinggi, keinginan siswa untuk bekerja setelah lulus, adanya pengaruh teman untuk tidak menjutkan studi ke perguruan tinggi dan adanya perbedaan antara siswa dan orang tua siswa mengenai jurusan yang akan ditempuh dalam studi di perguruan tinggi; 
e. Menurut guru bimbingan dan konseling ada beberapa siswa yang ingin langsung bekerja setelah lulus sekolah;

f. Peran guru bimbingan dan konseling dalam membangkitkan minat siswa dengan memberikan motivasi dan pentingnya pendidikan dalam menggapai masa depan;

g. Menurut guru bimbingan dan konseling yang menjadi kendala siswa tidak melanjutkan studi ke perguruan tinggi, yaitu faktor ekonomi orang tua siswa, tidak adanya keinginan di dalam diri siswa untuk melanjuti studi ke perguruan tinggi;

h. Dari hasil wawancara dengan guru bimbingan dan konseling, siswa yang telah diberikan layanan konseling dalam hal meningkatkan minat siswa dalam melanjutkan studi ke perguruan tinggi, yaitu siswa lebih memahami pentingnya pendidikan, siswa menyadari bahwa pendidikan salah satu faktor menggapai cita-cita dan membentuk masa depan yang lebih baik; dan

i. Evaluasi dari guru bimbingan dan konseling mengenai layanan yang telah diberikan kepada siswa, yaitu adanya keinginan siswa untuk melanjutkan studi ke perguruan tinggi, siswa lebih giat belajar, dan siswa yang ragu melanjutkan studi menjadi siswa yang antusias dan semangat untuk melanjutkan studinya ke perguruan tinggi.

Sedangkan hasil wawancara dengan Kepala SMK Nurul Hikmah Bekasi ada beberapa point yang dapat diambil, antara lain :

a. Dari hasil wawancara dengan kepala Sekolah SMK Nurul Hikmah Bekasi mengenai terlaksananya program bimbingan dan konseling dalam hal meningkatkan minat siswa melanjutkan studi ke perguruan tinggi sudah terlaksana dengan efektif dan efisien. Kepala sekolah memantau setiap minggunya program layanan bimbingan dan konseling yang dilaksanakan guru bimbingan dan konseling dalam hal memotivasi dan memberikan materi kepada siswa SMK Nurul Hikmah Bekasi.

b. Kepala sekolah memantau dalam penyusunan program yang telah dibuat oleh guru bimbingan dan konseling dalam hal meningkatkan minat siswa dalam melanjutkan studi ke perguruan tinggi.

c. Kepala sekolah mengevaluasi program yang telah dilaksanakan oleh guru bimbingan dan konseling dalam waktu, mingguan, harian dan bulanan.

d. Kepala sekolah memantau pelaksanaan program bimbingan dan konseling.

e. Dari hasil wawancara dengan kepala sekolah SMK Nurul Hikmah Bekasi mengenai program bimbingan dan konseling sudah terlaksana secara efektif dan efisien.

f. Dari hasil wawancara dengan kepala sekolah SMK Nurul Hikmah Bekasi, sekolah mengadakan kerjasama dengan pihak BKK (Bursa Kerja Khusus), dan HUBIN (Hubungan Industri) dengan beberapa industri yang ada di Bekasi.

Berdasarkan hasil wawancara yang peneliti lakukan dengan guru bimbingan dan konseling, kepala sekolah dan beberapa siswa SMK Nurul Hikmah Bekasi, maka dapat disimpulkan bahwa guru bimbingan dan konseling telah melaksanakan peran dan tugasnya sebagai guru bimbingan dan konseling secara maksimal. Guru bimbingan dan konseling juga berperan dalam meningkatkan minat siswa kelas XII untuk melanjutkan studi ke perguruan tinggi. Program layanan bimbingan juga dipantau oleh kepala sekolah agar layanan bimbingan dan konseling berjalan secara efektif dan efisien.

\section{Hasil Observasi}

Dari hasil observasi yang peneliti lakukan di SMK Nurul Hikmah Bekasi guru bimbingan dan konseling sudah melaksanakan tugas dan perannya sebagai guru bimbingan dan konseling yang terdiri dari program harian, mingguan dan bulanan. Salah satu program hariannya guru bimbingan konseling antara lain mengkontrol kehadiran siswa, kedisiplinan 
siswa, dan tata tertib lainnya sebelum jam masuk sekolah. Selanjutnya guru bimbingan konseling mengkontrol kelas yang sekiranya guru mata pelajaran tidak hadir untuk dapat dimanfaatkan layanan informasi terkait dengan motivasi siswa untuk dapat melanjutkan studi ke perguruan tinggi. Pada program mingguan, guru bimbingan konseling memberikan layanan individual maupun kelompok guna menumbuhkan minat siswa untuk dapat melanjutkan studi ke perguruan tinggi. Sedangkan program bulanannya adalah mengevaluasi dan memberikan layanan bagi siswa yang mengalami kasus maupun pelanggaran tata tertib sekolah dan mengevalusi program yang diberikan secara khusus kepada siswa kelas XII mengenai layanan untuk meningkatkan minat siswa melanjutkan studi ke perguruan tinggi. Serta memberikan layanan konseling bagi siswa yang mengalami prestasi rendah di mata pelajaran tertentu guna mencari tahu penyebab prestasi siswa yang rendah ataupun dibawah kurikulum yang berlaku.

Hasil observasi siswa SMK Nurul Hikmah Bekasi, siswa sudah mendapatkan layanan dan bimbingan konseling dari guru bimbingan dan konseling secara maksimal. Bagi siswa yang mengalami kasus maupun pelanggaran tata tertib, selalu di berikan layanan konseling dan sanksi jika dilakukan berulang kali. Bagi siswa yang mengalami kasus, dapat datang langsung ke guru bimbingan dan konseling untuk melakukan proses konseling guna mendapatkan arahan dan solusi. Sejauh ini kasus yang dihadapi siswa masih dapat ditangani oleh guru bimbingan dan konseling secara efektif dan efesien. Bagi siswa kelas XII mendapatkan layanan bimbingan dan konseling mengenai melanjutkan studi ke perguruan tinggi.

Kegiatan observasi yang peneliti lakukan menunjukkan bahwa perilaku setiap siswa terlihat baik, hubungan antara guru bimbingan dan konseling terjalin dengan baik, dan beberapa siswa juga berinteraksi lebih aktif dengan guru bimbingan dan konseling, serta sarana dan prasarana yang dimiiki oleh Sekolah Menengah Kejuruan (SMK) Nurul Hikmah Bekasi sudah tertata dengan baik.

Kondisi sarana dan prasarana sekolah sudah memadai seperti adanya, ruang kepala sekolah, ruang guru, ruang bimbingan dan konseling yang memadai dalam melayani proses konseling, ruang kelas siswa, perpustakaan, ruang Unit Kesehatan Siswa, laboratorium teknik komputer jaringan, laboratorium English Conversation, aula sekolah untuk sarana bimbingan kelompok, ekstrakulikuler, dan lapangan yang luas dan adanya fasilitas olahraga.

Pada saat observasi dilakukan, diperoleh informasi terkait dengan kondisi SMK Nurul Hikmah Bekasi yang dapat dikategorikan "baik" dalam mendukung kegiatan pelaksanaan layanan bimbingan dan konseling di sekolah, dimana pada kondisi ini terdapat suasana hubungan serta komunikasi antara guru bimbingan dan konseling dengan guru lainnya yang tergolong baik.

\section{Simpulan dan Saran}

Berdasarkan hasil penelitian yang dilakukan oleh peneliti di SMK Nurul Hikmah yang diperoleh melalui angket, wawancara, dan observasi di SMK Nurul Hikmah Bekasi menyatakan bahwa, dari hasil angket yang telah peneliti sebarkan kepada siswa XII TKJ (Teknik Komputer dan Jaringan) dan siswa kelas XII AP (Akademi Perkantoran) bahwa guru bimbingan dan konseling memberikan pemahaman tujuan melanjutkan studi ke perguruan tinggi, guru bimbingan dan konseling memberikan layanan konseling untuk membantu siswa memilih jurusan ke perguruan tinggi, serta guru bimbingan dan konseling juga berperan memotivasi dan meningkatkan minat siswa dalam melanjutkan studi ke perguruan tinggi. Berdasarkan hasil wawancara yang telah peneliti lakukan dengan kepala sekolah dapat disimpulkan bahwa, kepala sekolah memantau penyusunan program layanan bimbingan dan knseling dan mengevaluasi khususnya program bimbingan dan konseling untuk siswa kelas XII terkait minat siswa melanjutkan studi ke perguruan tinggi. Berdasarkan hasil wawancara yang telah peneliti lakukan dengan guru bimbingan dan konseling, disimpulkan bahwa guru bimbingan dan konseling telah memberikan motivasi mengenai pentingnya melanjutkan 
pendidikan. Program layanan bimbingan dan konseling telah diberikan kepada siswa kelas XII terkait motivasi dan minat melanjutkan studi ke perguruan tinggi. Dari hasil observasi di sekolah dapat disimpulakan bahwa, kondisi sarana dan prasarana di sekolah cukup memadai, kondisi lingkungan di sekolah cukup nyaman, rapi dan bersih. Sarana dan prasarana ruang guru bimbingan dan konseling dapat menunjang proses bimbingan dan konseling secara kondusif. Sarana dan prasarana di sekolah memberikan dampak proses belajar mengajar secara maksimal. Berdasarkan hasil penelitian secara keseluruhan, maka peneliti menarik satu simpulan bahwa "Peran Guru Bimbingan dan Konseling dalam Meningkatkan Minat Melanjutkan Studi ke Perguruan Tinggi pada Siswa di SMK Nurul Hikmah Bekasi”, dalam kategori Baik.

\section{Daftar Pustaka}

Daryanto, \& Farid, M. (2015). Bimbingan Konseling Panduan Guru BK dan Guru Umum. Yogyakarta: Gava Media.

Djamarah, Syaiful, B., \& Zain, A. (2002). Strategi Belajar Mengajar. Jakarta: Rineka Cipta. Gantina, Komalasari, \& Wahyuni, E. (2011). Teori Teknik Konseling. Jakarta: Indeks.Gunarsa.

Mulyasa, E. (2003). Kurikulum Berbasis Kompetensi. Bandung: PT. Remaja Rosdakarya. Prayitno, \& Amti, E. (2009). Dasar-Dasar Bimbingan dan Konseling. Jakarta: Rineka Cipta. Syah, M. (2010). Psikologi Pendidikan Dengan Pendekatan Baru. bandung: Remaja Rosdakarya.

Usman, U. (2017). Menjadi Guru Profesional. Bandung: Rosdakarya.

Wardati, \& Jauhar, M. (2011). Implementasi Bimbingan dan Konseling Di Sekolah. Jakarta: Prestasi Pustaka Raya. 